\title{
LIGHT RAIL TRANSIT AND LAND USE IN QATAR: AN INTEGRATED PLANNING STRATEGY FOR AL-QASSAR'S TOD
}

\author{
Raffaello Furlan* and Mooza AlMohannadi \\ Department of Architecture and Urban Planning, \\ Qatar University, \\ Doha, State of Qatar
}

\section{${ }^{*}$ Corresponding Author's email address: raffur@gmail.com}

\begin{abstract}
The State of Qatar is presently facing the development of major transport infrastructure, to be finalized (A) by 2022 for the planned FIFA World Cup and (B) by 2030, as envisioned by the comprehensive national development planning strategy, also named Qatar National Vision (QNV-2030). The under-development metro system foresees the construction of four main lines. In addition, Doha, the capital city of the State of Qatar, is experiencing the progress of (1) prestigious mega projects and (2) several transit villages around the major metro stations. These projects are the manifestation of the deliberate attempt of Qatar to establish Doha as the service, economic and cultural hub of Middle East. Currently, traffic is considered a major concern: 'Park-and-Ride' facilities along train stations may reduce the general amount of vehicles on the road network and provide a 'stress-free' passenger experience when transitioning to and from the new Doha Metro System. Therefore, one of major challenges for urban planners is guaranteeing that all metro-stations and facilities $(A)$ are fully integrated within the urban context of their surroundings and $(B)$ provide multi modal transportation facilities. This urban planning strategy aims at reducing traffic through the design of compacted, mixed used transit villages, or Transit Oriented Developments (TODs). This paper explores the case of the neighborhood of Al-Qassar metro station. The exploration starts with the review of the relevant literature and the analysis of the site. Finally, the resultant planning-strategy for an integrated conceptual development of ALQassar-TOD envisions the development of a compact transit village, which contributes to reduce the traffic, to enhance pedestrian connectivity and to shape a liveable community.
\end{abstract}

Keywords: Land use; built environment; transit villages; Al-Qassar metro station

\section{INTRODUCTION}

Over the past two decades Qatar witnessed a rapid urban growth, which transformed its capital city, Doha, from a small port town to a large sprawling city. This occurred as a result of the export of oil and gas, which currently account for over $50 \%$ of Qatar's Gross Domestic Product (GDP). During this time Qatar engaged a large megaprojects' campaign to attract global investments and tourists. This led the state government to initiate investments for the construction of new infrastructure and facilities, including highways, railways, ports, airports, stadiums and hotels (Salama, 2013; Salama \& Wiedmann, 2013; Salama et al. 2016).

The State of Qatar is currently facing the construction of a new metro system, which includes the creation of approximately 100 metro stations along 4 main lines: the red, gold, green and blue lines. One of its major underground Metro stations, Al Qassar, is located along the Metro Red Line on the eastern side of Qatar in-between the West Bay Central metro station and Katara Cultural Village metro station (Furlan \& Faggion, 2015a; Shaaban \& Radwan, 2014). 

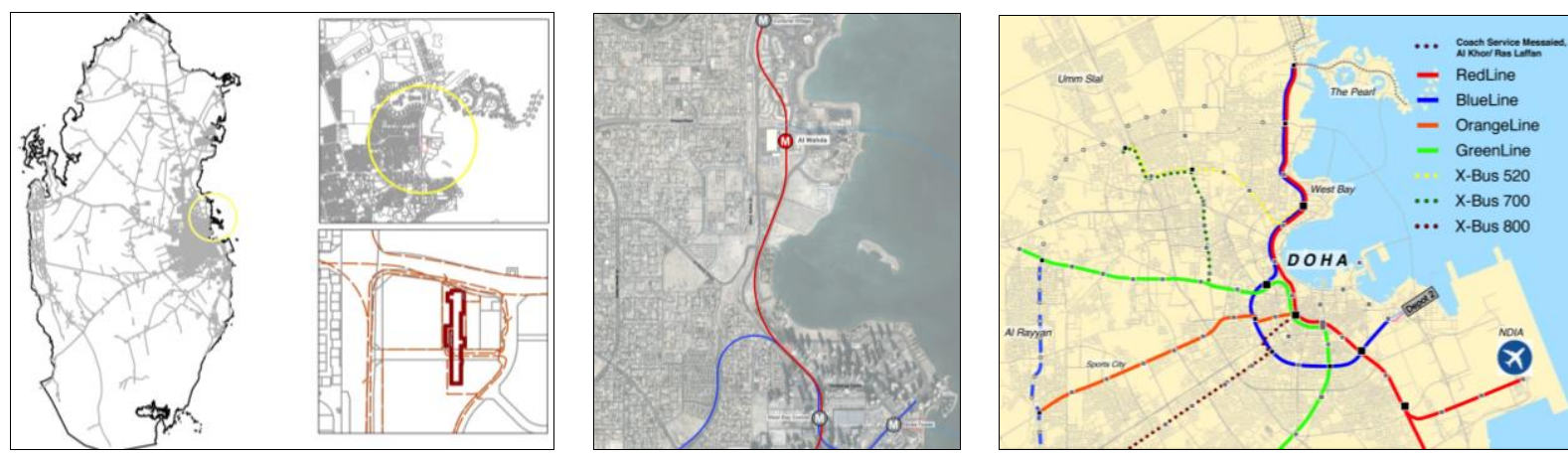

Figure 1, 2, 3. ALQassar Station located along the Metro Red Line (Source: Authors).

Currently, there are minor studies exploring the formation and implementation of efficient transit villages (or TODs) in Qatar, namely in sight of the metropolitan urban growth of Doha and of the consequent increase of the vehicular congestion and suburban sprawl (Remali, Salama, Wiedmann, \& Ibrahim, 2016; Wiedmann, Mirincheva, \& Salama). The aim of this paper is to reveal an urban design strategy for an integrated conceptual development of the AL-Qassar-TOD, namely to develop a compact transit village (1) fully integrated within the urban context of its surroundings, (2) offering multi modal transportation facilities, which in turn contribute (3) to reduce vehicular congestion, (4) to enhance pedestrian connectivity and (5) to shape a liveable community.

\section{BACKGROUND}

Scholars and researchers stress that urban design principles leading to sustainable urban developments and smart growth can be defined through the exploration of strategies that have successfully implemented the built environment of existing cities. Several urban-social movements encourage the formation of sustainable, resilient and liveable communities and cities, through specific urban design principles (Alexander, 1987; Brown, Dixon, \& Gillham, 2014). The first one is to enhance liveability by getting access to daily-use facilities and services within walking distance; the second one is to create a livable community through community engagement; the third one is to expand economic opportunities; the fourth is to promote equality by providing social equity services; and the last one is to foster sustainability, namely when confronted with climate change, and to improve users' quality of life. Scholars argue that these key-factors have a cardinal impact on the design and planning of urban developments (Day, 2003). Most of the aforementioned principles encourage connectivity, integrated modes of transportation, formation of green areas and/or open spaces enhancing social interaction, planning of compact communities, which provide all residential needs within walking distance (Furlan, 2015). Scholars argue that these principles lay the foundations for the design and planning of sustainable and livable urban communities and/or TODs (Carmona, Tiesdell, Heath, \& Oc, 2010).

\section{Smart Growth}

Smart growth, a contemporary major urban design and planning movement, focuses on directed growth and controlled sprawl, encouraging investments in the development of the built environment and preservation of the natural environment (Hawkins, 2013; Miller \& Hoel, 2002). 'Pedestrian accessibility', 'walkability' and 'multi-modal transport systems' are the key-factors envisioned by smart growth: the movement proposes a reduction of use of private vehicles, a development of high-density compacted areas with emphasis to pedestrian network. In turn, applying this urban planning strategy can contribute to limit urban sprawl (Farr, 2008). This is also stressed by Julie Brand Zook, Yi Lu, Karen Glanz, and Craig Zimring (2011), who argue that smart growth comprises the enhancement of multiple and various transportation systems, pedestrian pathways (walkability), mixed land use, human scale and design. 
Wann-Ming Wey and Janice Hsu (Wey \& Hsu, 2014) highlight the existence of differences and similarities between new urbanism and smart growth. New urbanism focuses majorly on architectural methods for implementing the built environment, whereas smart growth focuses on land use from a planning perspective. Along similar lines, Yonn Dierwechter (2013) argues that smart growth creates urban spaces. A positive reading of this approach lies on its comprehensiveness: both architectural and urban developments support smart growth.

A further key-factor, which contribute to achieve smart growth and create livable communities (Furlan, Muneerudeen, \& Khani, 2016) is mixed land use, which allowing people to meet their needs without commuting or using their cars. This principle promotes the creation of pedestrian driven or healthier neighbourhoods and the fostering of urban connectivity. In these communities, it should be safe and easy to move, and the resulting strong local economies should further support the smart community movement (Furlan, Almohannad, Zaina, \& Zaina, 2015; Furlan, N.Eiraibe, \& AL-Malki, 2015).

For instance, in Al Khor city (North of Qatar), planners have demolished several waterfront houses and replaced them with a new traditional souk market, located within a walking distance from the neighbourhood. These urban interventions, encouraging local businesses' development and attracting investors, finally contribute to smart growth for communities. It might be convincingly argued that outdoor common areas evince a more urban liveliness than shopping malls do. In comparison, Christopher Hawkins (Hawkins, 2013) has proposed a view of zoning supporting economic development via an increase in smart growth. The most important element of such a proposal is determining how and the extent to which urban open spaces can be designed as per users' sociocultural factors, in order to enhance liveability and/or people way of life (Furlan, Almohannad, et al., 2015; Givoni, 1989; Kaspirin, 2011).

Further research in this area explores planning policies and regulations, encouraging the principles of smart growth through high-density developments, which allow people to access facilities, social and educational services within walking distances. Scholars argue that the following strategies allow planners to smartly control urban growth and sprawl: (1) Growth management - in the 1970s, Michael Dukakis shared concerns about mountain highways, wanting to support sprawl and natural preservation to manage growth; (2) Pedestrian pockets - this concept, proposed by designer Peter Calthorope in 1989, encourages compact growth via transit, linking mixed-use communities within walkable distances; (3) Livable streets or streets as destinations - Integrating modes of transportation within mixed-use communities and promoting community activities both encourage people to walk and increase social equity (Calthorpe, 1993; Calthorpe \& Fulton, 2001; Cervero, 2000; Cervero \& Kockelman, 1997).

In summary, urban public transit systems and land use have a severe impact on the design and planning of smart cities. Urban connectivity and high density have also a crucial effect on smart growth. It has been shown that several key-aspects, such as social, economic, political, and environmental, can lead to the development of healthier and more sustainable communities. Furthermore, political aims have a major impact on smart growth, starting with regulations leading to high-density mixed-use areas, which provide multiple services in the same place and contribute to prevent the need for people to commute and traveling from place to place for meeting their needs. Therefore, it is argued that these principles can lay the foundation for the smart-growth planning of Qatari cities and municipalities.

\section{New Urbanism}

New urbanism is an urban design movement pursuing the formation of physical environments for diverse, resilient communities. Scholars have considered the patterns of modern urbanism based on historic neighbourhoods, including diversity and pedestrian walkability, to encourage social interaction. The fundamental goal of new urbanism is to create a better quality of life enabled by the Archnet-IJAR, Volume 10 - Issue 3 - November 2016 - (170-192) - Original Research Articles 
implementation of urban frameworks (Saliba, 2015). Early adaptation of the new urbanism-concept began with a small group of architects and urban planners when cars became the main mode of transportation and most cities across the world started to plan and develop their built environments around the use of cars, ignoring vital aspects such as walkability (Furlan, Eissa, Awwad, \& Awwaad, 2015; Furlan, Nafi, \& Alattar, 2015). In the late 1970s, planners started to implement new regulations and guidelines focusing on traditional communities in the United States. Their implementation in the urban planning of small towns in America had a severe impact on the success of the new urbanism concept. In turn, towns attracted investors and developers, who began to design traditional urban neighbourhoods, characterized by human-scale streets and mixed-use residential areas. This approach to new urbanism encouraged a strategy for successful development (Day, 2003; Wey \& Hsu, 2014).

In 1993, new urbanism as a movement brought together planners, architects, designers, environmentalists and other specialists who argued that physical urban growth have a cardinal impact on the environment and that neighbourhoods and public spaces contribute to generate healthy communities, characterized by successful places for people.

New urbanism remains the most significant and influential movement in the contemporary area of urban design and architecture. The main two key-factors the movement concentrates on are (1) human needs and (2) public health. In addition, the Charter of the New Urbanism (CNU) has implemented specific guiding principles surrounding public policy, development practices, urban design and planning, which can be applied on a range of scales (Wey \& Hsu, 2014).

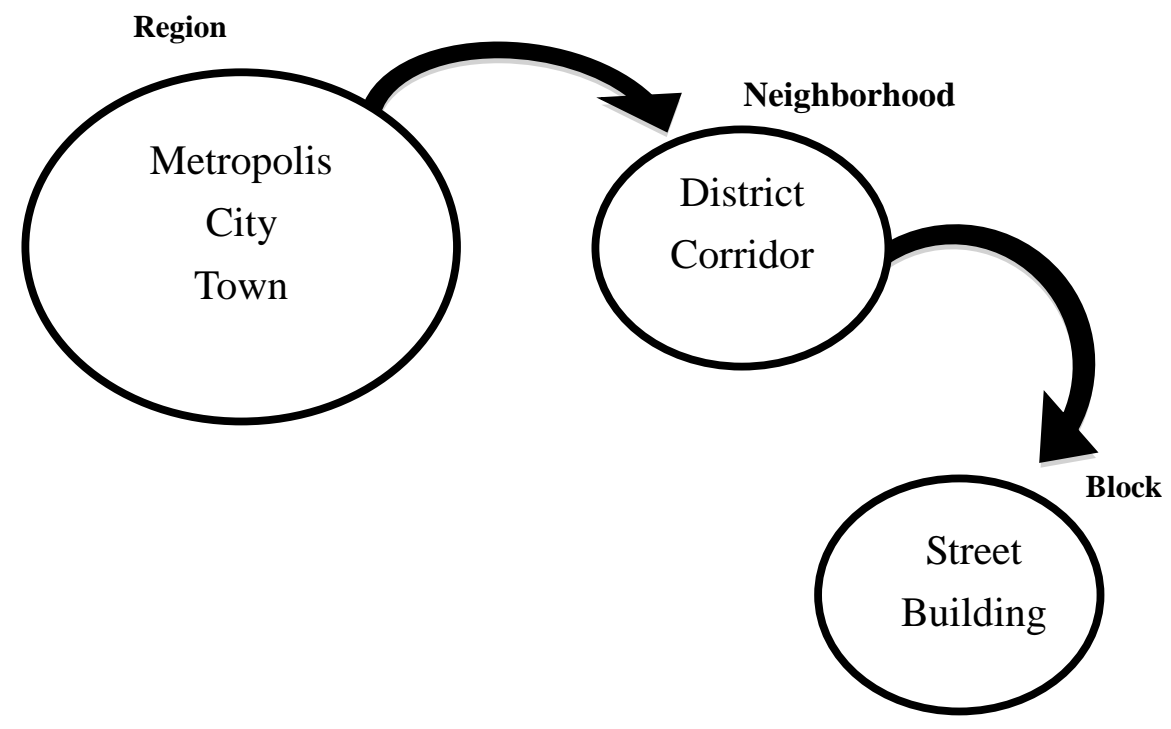

Figure 4. Urban planning and design scales (Source: Authors).

There are geographic boundaries for each category, including specific patterns focusing on many aspects of the development, such as economics, work opportunities, transportation, social fabric, the environment and natural resources, which are meant to provide compacted mixed-used areas (commercial, government, residential, etc.) and a variety of transit stops and open public spaces enhancing social interaction.

In the early twentieth century, the implementation of new urbanism principles under urban renewal in many neighbourhoods became successful. Kristen Day (Day, 2003) argues that the new urbanism approach is based on design strategies to control suburban sprawl and to build up and rebuild cities, towns and communities. The new urbanism movement was promoted by organizations focusing on

Archnet-IJAR, Volume 10 - Issue 3 - November 2016 - (170-192) - Original Research Articles 
cultural preservation, urban renewal, dense neighbourhoods, human-scale streets, commercial centres and small businesses, transport systems, pedestrian walkways and mixed-use streets, with the aim of improving the built environment.

In the past two decades Qatar has developed rapidly and the guidelines of new urbanism are followed for future developments, especially in up coming and under development megaprojects. Most of these principles concentrate on sustainability, multiple transportation systems, compacted mixed-use areas in addition to cultural preservation through the implementation of old patterns of development, using traditional styles and design (Furlan, 2016; Furlan, N.Eiraibe, et al., 2015).

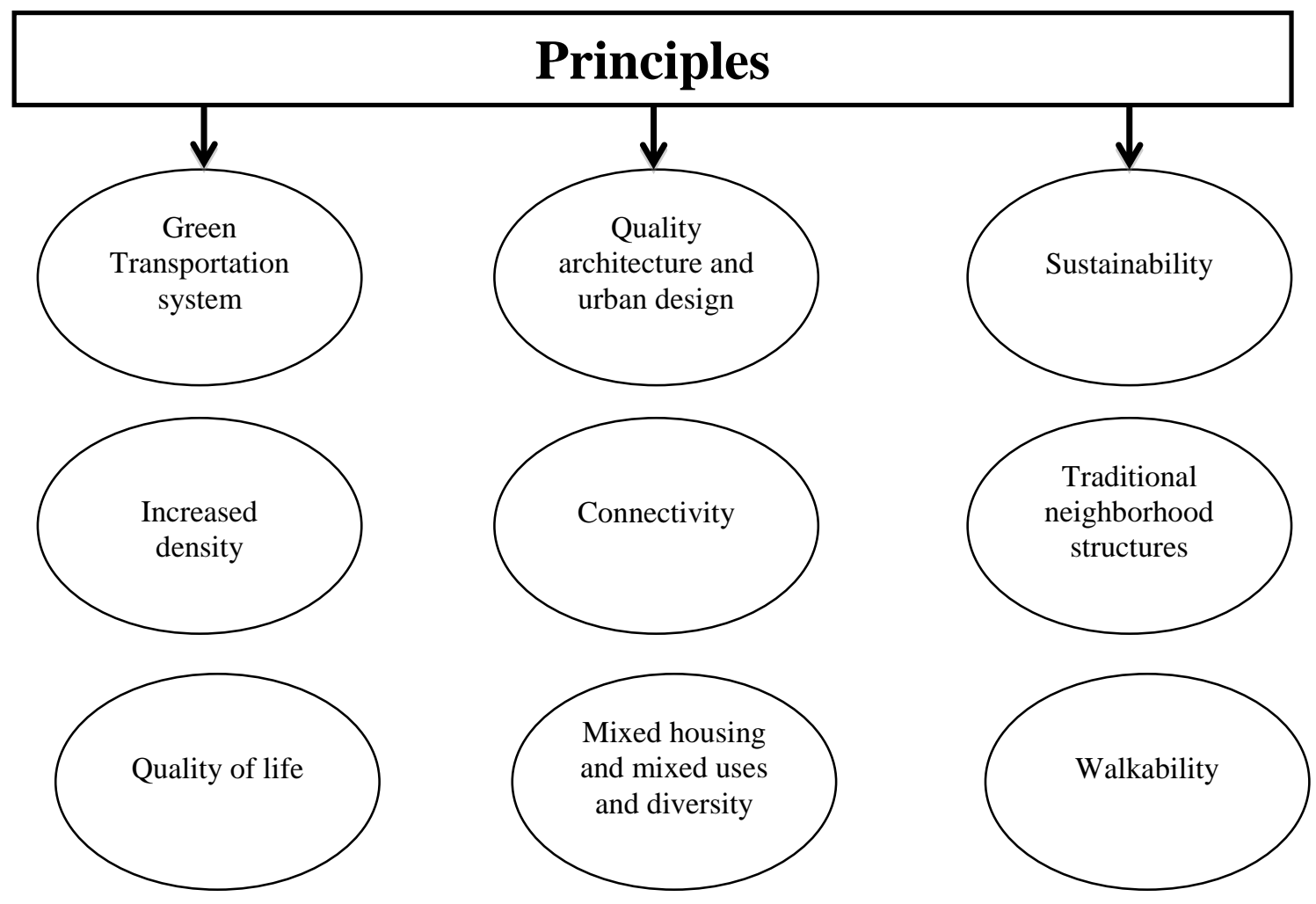

Figure 5. Planning principles of new urbanism (Source: Authors).

Additionally, the concept of landscape urbanism supports new urbanism by concentrating on a holistic approach to design the city. In 1969, in his book Design with Nature, lan McHarg took an approach named as 'ecological planning and design' (cited in Conan, 2000), which focuses on regional and city planning with consideration to climatic conditions. In 2006, James Corner (Corner, 2006) renewed McHarg's ideas in his essay "Terra Fluxus," published in The Landscape Urbanism Reader. He broadly defined landscape urbanism as the urban development that grows around natural and human implementations of landscapes, rather than around highways, and therefore depending on the natural environment to shape the urban development. While some scholars argue that landscape urbanism promotes the important principle of shaping, organizing, and designing built environments, others argue that landscape urbanism is "emo urbanism," trying to connect a modern ecological approach with urban design in relation to human emotions and needs.

In the twenty-first century, the two concepts of landscape urbanism and urban ecology have posed the following question: How can we plan and design livable cities? Landscape urbanism developed from

Archnet-IJAR, Volume 10 - Issue 3 - November 2016 - (170-192) - Original Research Articles 
urban design theories as a way of planning by focusing on city landscape designs rather than on buildings (Steiner, 2011). However, landscapes also have a huge impact on built environments, as do natural aspects within urban areas have. For example, micro climatic conditions within implemented landscapes raise and lower temperatures to create comfortable environments, especially in hot, arid regions.

\section{Green Urbanism}

The Green Urbanism movement began in the United States in the early 1980s (Lehmann, 2010). Over the past decade, the movement has raised significant strategies to reduce cities' negative impacts on the natural environment. Green Urbanism aims at shaping more sustainable urban areas and communities by reducing (A) negative emissions and ecological footprints, which contribute to produce eco-urban developments, and (B) use of energy and water (Farr, 2008).

Scholars argue that recently emissions of carbon dioxide have hugely impacted air pollution levels. For example, in Qatar, fossil fuel is used to generate electricity, more than $60 \%$ of which is used for air conditioning of buildings. During hot summer days, the increased demand for energy for cooling of buildings results in increased air pollution through the burning of fossil fuels (Lehmann, 2010).

Scholars envision different ways to achieve sustainable urban development. While a few emphasize urban areas with zero emissions, others promote the enhancement of existing urban areas in order to make them more sustainable. Scholars also focus on the ways urban areas are shaped and their positions within cities with regard to, for instance, water self-sufficiency, food production, building materials and energy, all of which play a major role in reducing negative emissions (Jamei, Rajagopalan, Seyedmahmoudian, \& Jamei, 2015).

Along similar lines, compact urban areas, in which all residential needs are available within walking distance, will reduce commuting and the need for cars, as well as enhance quality of life. Building management, infrastructure and resources are three major aspects in creating eco-districts, controlling and reducing negative impacts on the environment by managing waste distribution, energy, and natural resources.

Green urbanism could be applied within new developments in Doha by implementing modes of public transportation and therefore trying to reduce negative emissions from cars. There are several undergoing large urban scale sustainable developments in Doha, such as Lusail city, where new ways of mobility are proposed in order to minimize negative impacts on the natural environment. In addition, for instance one of the objectives of Msheireb Properties is to reduce the demand for water and ensure its efficient distribution. The strategy for the implementation of these developments clearly reveals that Doha is aware of the significance of shaping sustainable communities within its built environment (Salama, 2013; Wiedmann et al. 2013). Therefore, it is argued that the principles for green urbanism can be applied within the construction of transit-oriented developments (TODs) in Doha. 




Figure 6. Green urbanism Principles (Source: Lehmann, 2010)

\section{Transit Oriented Development}

Peter Calthorpe defined 'Transit-Oriented Development' (TOD) in the late 1980's as "a mixed-use community that encourages people to live near transit services and to decrease their dependence on driving." TOD became a fixture of modern urban planning when in 1993 Calthorpe published his acclaimed book "The New American Metropolis" (Calthorpe, 1993).

TOD is not just a recent urban phenomenon. At the beginning of the $20^{\text {th }}$ century, in a period preceding the car ownership, scholars studied the relationship between the development of street car, 
commuter railway journeys and urban form (Knowles \& Sweetman, 2004). From the post WWII period until the 70s, most Western European cities experienced rapid urban development and population growth due to immigration of people from rural areas to cities. This lower density suburban expansion was faster by the rapid rise of private car ownership (Knowles \& Sweetman, 2004). Scholars argue that TODs can increase access to public transportation, work places, educational institutions and other facilities by promoting transportation options to households. Destinations, Distance, Density, Design, Diversity and Demand Management are the well-known six Ds, which are consider as the basic principles providing the maximum benefits of TOD for communities (corridors of opportunity). As a result, this creates an increased transit ridership, encourages a safe and pleasant pedestrian environment near transit stations, limits clashes between vehicles and pedestrians and finally reduces road and traffic congestion.

In addition, TODs contribute to reduce urban sprawls and parking requirements by encouraging shared parking and different system of transportation. Scholars also argue that TODs make neighborhoods more livable because a sense of activity and liveliness is encouraged (Besser \& Dannenberg, 2005).

TOD is a type of community-development, which includes a mixture of housing, office, retail and other amenities integrated into a walkable neighbourhood and located within a half-mile of public transportation. It is characterized by $(A)$ moderate to high density development, which supports public transport (PT) services at the nodes; (B) a mix of land uses (e.g. residential, commercial, recreational, and institutional) to facilitate and attract activity participation within the places; (C) well-connected street networks so that activities can be integrated with active transport. TOD is not just related to the planning of transit stations, but it significantly refers to the development of places where inhabitants can live, shop, recreate and socialize. TOD is an urban development characterized by centralized decentralization (Cervero, 2000; Cervero \& Kockelman, 1997).

\section{METHODOLOGY}

The case study of Al-Qassar metro station was chosen cause of its cardinal role in the development of TODs in Qatar, where the concept of TODs is gaining critical relevance as an urban design strategy to integrate land use and transit systems. In December 2015, three one-to-one conversation-meetings were conducted with leading planners from $(A)$ the Ministry of Municipality and Urban Planning (MMUP), (B) Ashghal-Public Works Authority and (C) Qatar Rail to discuss the planning policies for the development of TODs in Qatar. The master-plan inclusive of the urban planning policies/standards for the developments of urban villages in Qatar was assessed through un-structured, exploratory questions. This allowed to build a qualitative, in-depth understanding of the multi-faceted urban development strategies and challenges in Qatar and to identify the patterns that characterize the planning of TODs in Qatar.

Afterwards, visual data has been collected through site visits, maps, drawings and photographs of the area under investigation, namely the existing site and surrounding major destinations, as well as the under-implementation transport infrastructure. The authors conducted site visits to gain a better overview of the existing status of the built environment, land-use, climatic condition, community requirements and connectivity to the surrounding areas (Creswell, 1994, 2003; Denzin \& Lincoln, 2005; Dunn, 2005; Marshall \& Rossman, 2006; Mason, 2001; Zeisel, 1984).

\section{FINDINGS}

The findings are structured into two main sections: the (A) site analysis and (B) Al-Qassar's TOD. The first section enabled the identification of five thematic key-factors - land use (i.e residential, commercial), connectivity, mixed-use (diversity), density and landscape (public open spaces and/or parks) - which, in turn, represent the foundation principles for planning the transit village around $\mathrm{Al}$

Archnet-IJAR, Volume 10 - Issue 3 - November 2016 - (170-192) - Original Research Articles 
Qassar Station, as graphically proposed in the second section, where the conceptual design for the TOD of Al Qassar has been developed in accordance with the revealed key-factors.

\section{SITE ANALYSIS}

Al Qassar Station (Metro Red Line) is located on the eastern side of Qatar (see figure 7) in-between the West Bay Central metro station (South) and Katara Cultural Village metro station (North). Onaiza Road bounds the site to the north, which will connect to the Sharq Crossing, whilst the West Bay Road/Lusail expressway is located to the east of the site. By 2021 it will extend from Lusail Center, located approximately $12 \mathrm{~km}$ north of West Bay, to Al Wakra North, located to the south of Doha. As per the under construction project (as shown in figure 7), the station, platforms and tracks are underground. Escalators, stairs and lifts will be provided to enable users to access and exit the platforms from ground level.

From the analysis of gleaned responses, perspectives and visual data, four major criteria emerged, which contributed to discuss the Strengths, Weaknesses, Opportunities Threats (SWOT) analysis. In turn, the further assessment of these criteria through the SWOT analysis will contribute to define five thematic key-factors for planning Al Qassar TOD.

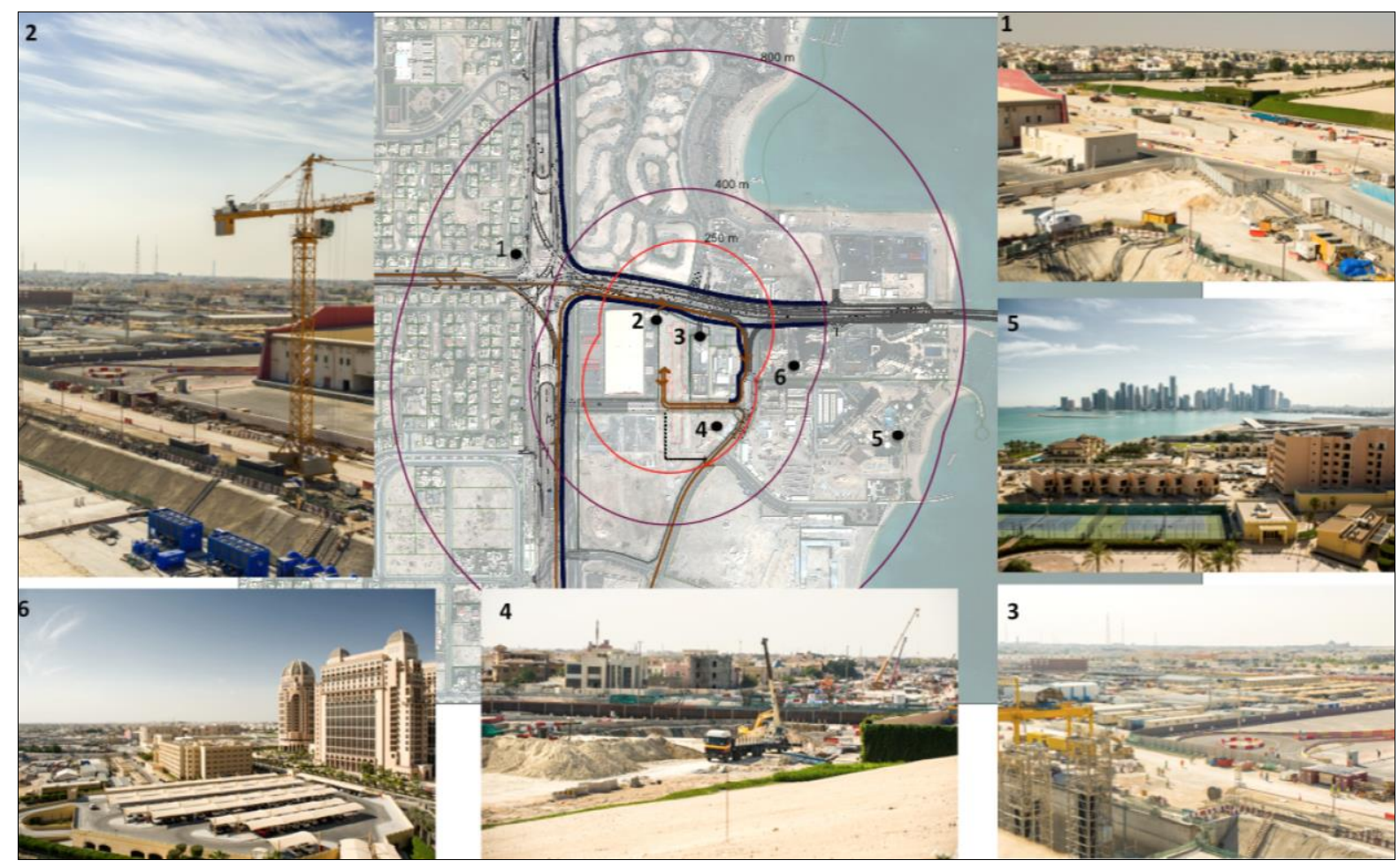

Figure 7. Map and photographs of Al Qassar area (Source: Authors).

\section{Infrastructure-Projects}

There are major projects for motorways' implementation proposed in the proximity of the metro station. The Lusail Expressway is a multi-lane grade-separated strategic highway, which will connect West Bay to Lusail city (North of Doha). Restricted movements at certain junctions, including the one adjacent to the proposed metro station have been incorporated into the existing TOD's design in order to enhance the free flow of vehicles on the main carriageway. 

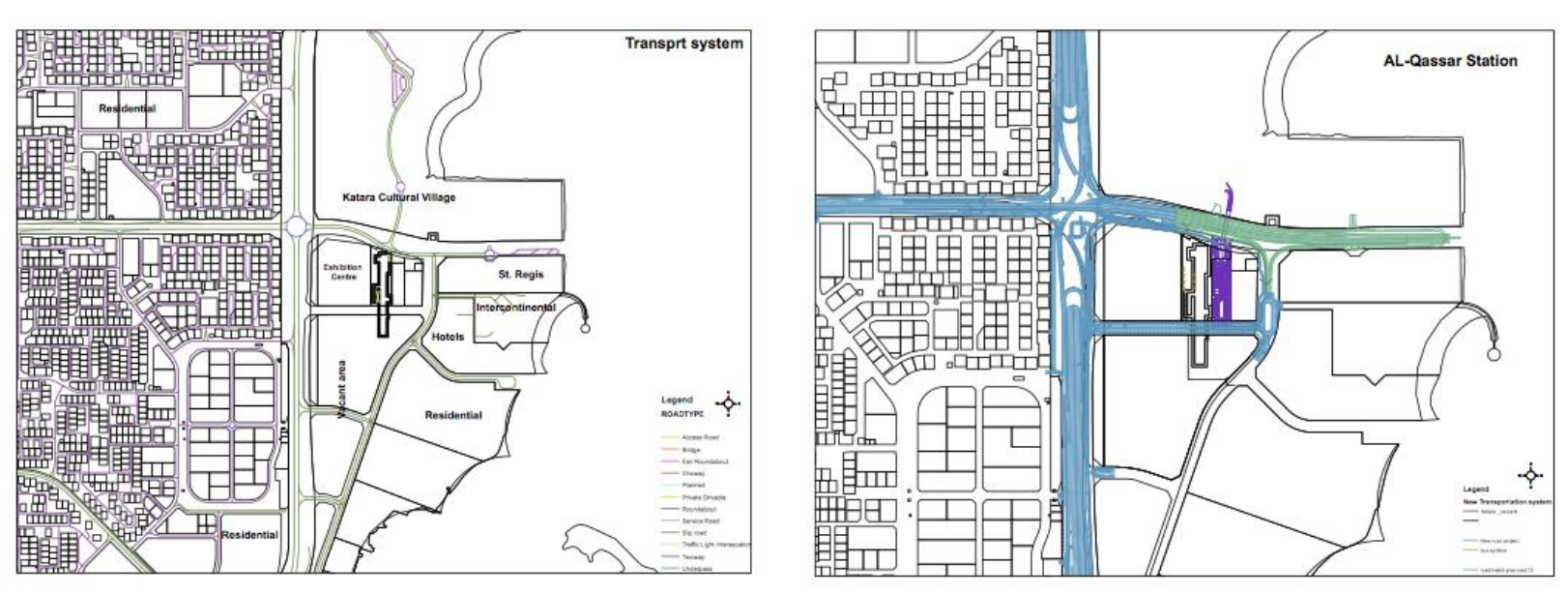

Figure 8. Vehicular accessibility and circulation diagram (Source: Authors).

Vehicular accessibility is provided to Al Qassar metro station from Lusail Expressway (see figure 8), which, as reported by Qatar Rail, should be completed by the end of 2016. The selected area for intervention is confined to $250 \mathrm{~m}-400 \mathrm{~m}$ radius-walking and $800 \mathrm{~m}$ catchment areas within the station area. This distance has been chosen, being considered as a comfortable pedestrian distance from the major public transport services. Within the mentioned $800 \mathrm{mt}$ radius area there are several attractive destinations, including the Doha Exhibition Centre, Katara Cultural Village, residential compounds and also a few luxurious hotels, such as the St. Regis and Intercontinental Hotel. These destinations, considered as major landmarks within the area, generate trip from and to the station.

\section{Climatic Condition}

Qatar has a dry, subtropical desert climate, with low annual rainfall and intensely hot and humid summers. Normally, while from May to September the average temperature is about $42^{\circ} \mathrm{C}$, from October to April it drops to $23^{\circ} \mathrm{C}$. Commonly the wind blows from North with a breeze blowing toward the land from the sea. The sun path diagram shows an overview of the sun on the site. Figure 9 shows the sun path, which is of cardinal relevance to the outcome of the project. The shaded and street furniture should be planned in accordance to the sun orientation, in order to attract people to the station and provide accessible and shaded open spaces, green areas, facilities and services. 


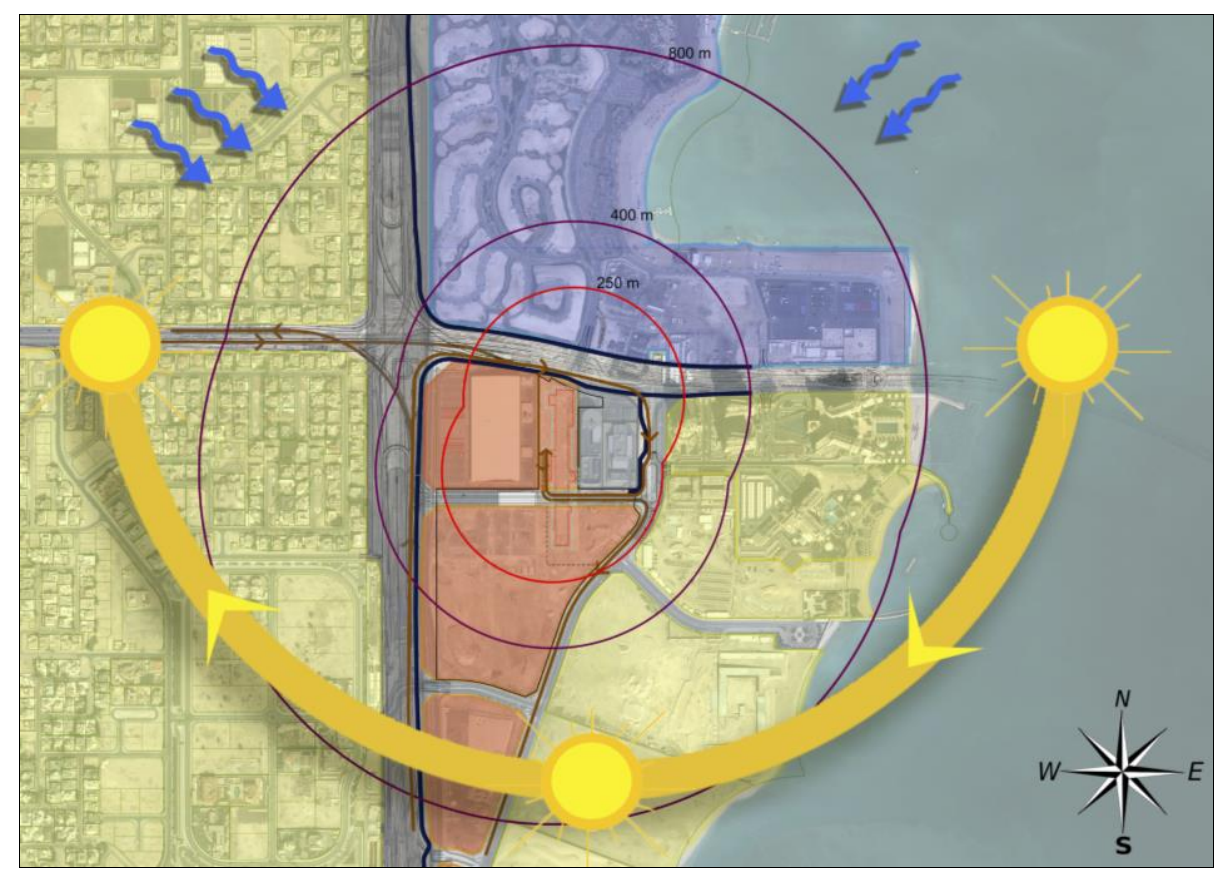

Figure 9. Site's sun path diagram (Source: Authors).

\section{Building Height and Land Use}

The buildings surrounding the station, with a height varying from ground plus 2 and 3 floors $(G+2$ and $\mathrm{G}+3$ ), are mainly planned for residential and commercial use. Two existing hotels with a height superior to 8 floors are visible from the figure below.

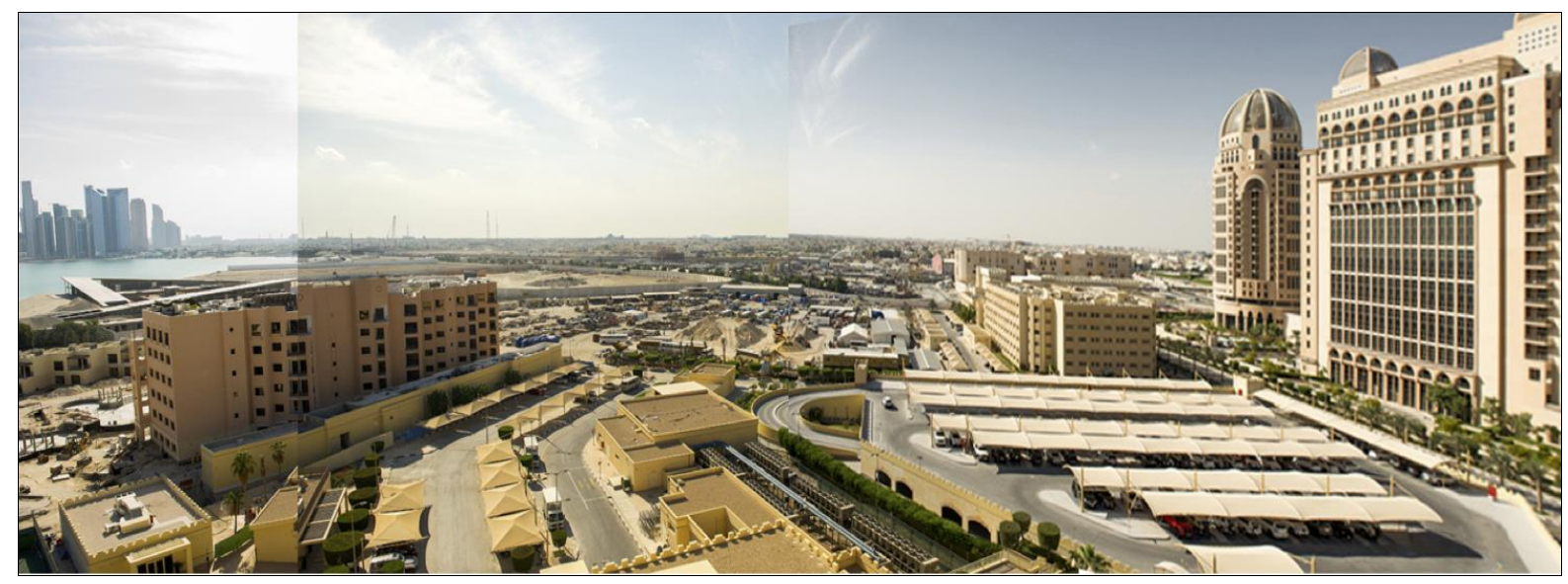

Figure 10. The buildings surrounding the area (Source: Authors).

\section{Bus Station}

Qatar Rail proposed the development of a bus station, which connects buses to the train station and to the major destinations in a distance of $800 \mathrm{mt}$. This further public transportation service through the neighbourhood will provide commuters a further mode of public transportation, which will reduce the use of cars. 


\section{SWOT Analysis}

The discussed analysis allowed conceptualising strengths, weaknesses, opportunity and threats (SWOT) for the site under investigation and related TOD (see figure 11). While the closeness to several attracted areas is a strength, the lack of open spaces and green areas as well as the pedestrian and the public transportation system are a severe weakness. The opportunities of implementing are directly related to the enhancement of liveability around the selected area. Furthermore, the rail station may cause further congestions and traffic to the areas, which is already occurring namely in the rush hours.

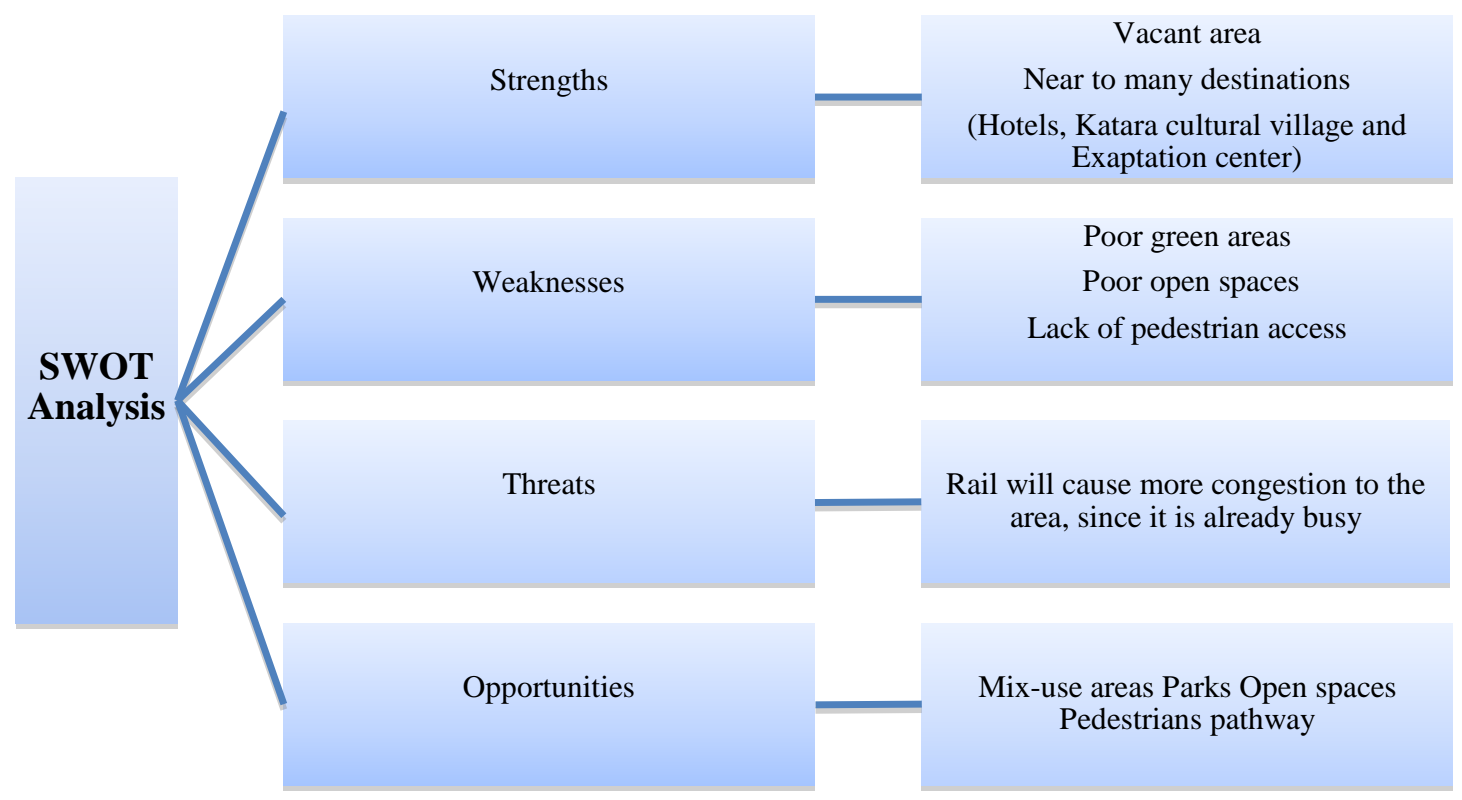

Figure 11. Swot-Diagram (Source: Authors).

\section{AL QASSAR'S TOD}

The proposed approach for planning the liveable and vibrant transit village of Al Qassar is based on five thematic key-principles:

- Integration with multiple modes of transport (connectivity and ease to use)

- Land-use (mixed use \& diversity development);

- Major destinations (accessibility);

- Density;

- Natural Environment (Landscape, use of Public Space and green areas); 


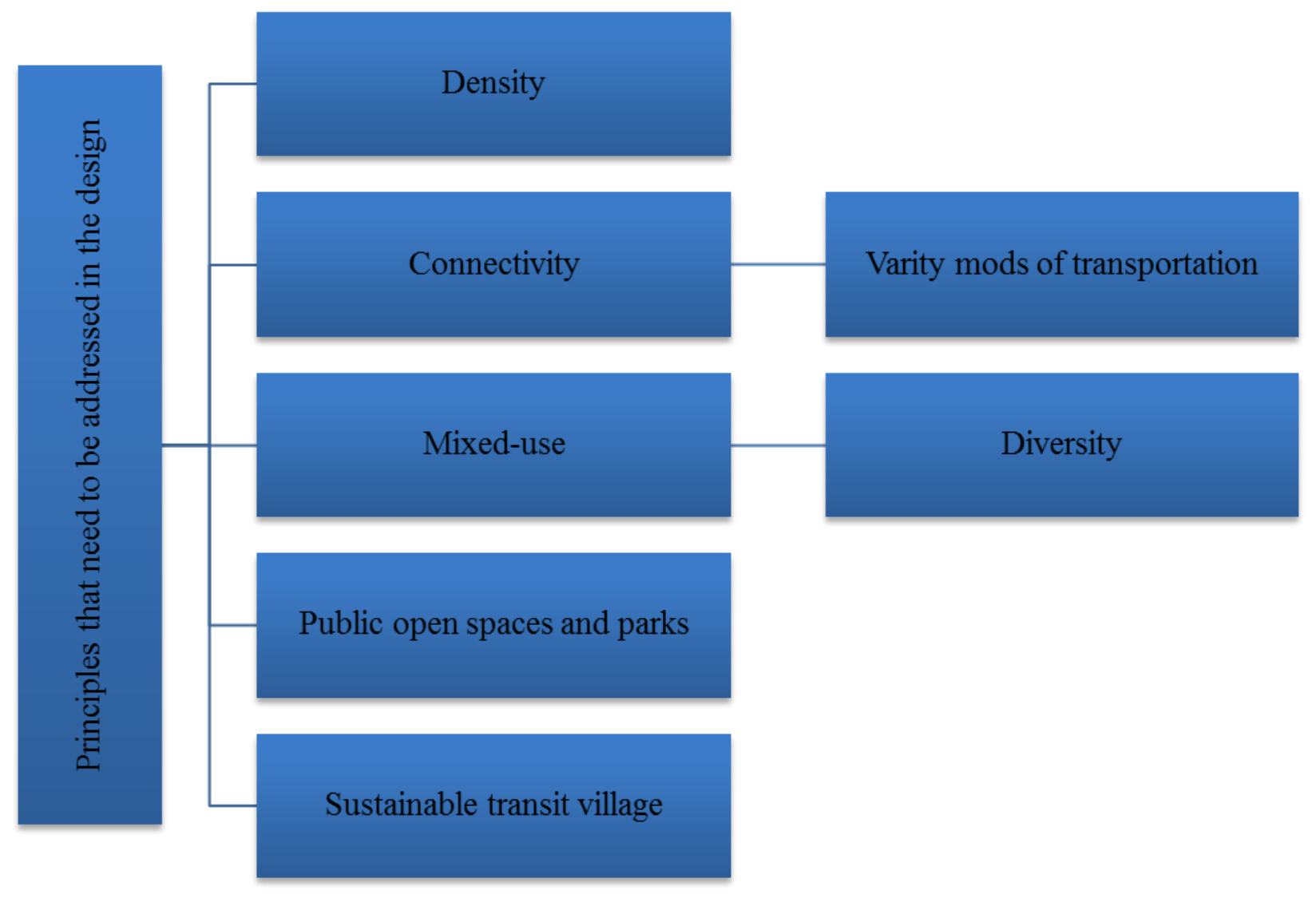

Figure 12. Design Principles for the Development of the Transit Village of AL-Qasar (Source: Authors).

The comprehensive conceptualisation of AL-Qasar's TOD bases its foundation on the key factors listed above, which lead to the development of a compact transit village, where the needs of the residents and commuters' are addressed within a walking distance and/or with comfortable microclimate condition. In turn, this strategy will facilitate to minimize suburban sprawls and enhance quality of life of users, as envisioned by planners and scholars adhering to the smart growth, new urbanism and green urbanism movement, reviewed in the literature.

\section{Modes of transport (Connectivity)}

Pedestrian access to the urban development is encouraged and should be enhanced for a seamless and safe journey, as this is the most convenient and sustainable mode of transport. Low-rise residential buildings are located to the west of the station. Concurrently, appropriate pedestrian services enhance the walkability and pedestrian movement to and from the metro station. Shaded devices and street furniture along plazas, open spaces and green areas facilitate the performing of outdoor daily activities. The development of an efficient footbridge network will also facilitate linkages and/or connections between buildings and the surrounding public open areas.

In relation to cycling, Qatar National Bicycle Master Plan (2008) has included cycle routes to be developed within Doha. The proposed Lusail Express-way design is to develop a cycle path along this route. The cycle parking is appropriately located nearby to the station. The development of cycling pathways will offer effective transport alternatives to driving and the use of buses will contribute to 
enhance streets' liveability. Also, providing renting and/or sharing bikes and parking spots within the transit village will promote the use of bicycles.

Developing an efficient public transport system connecting major surrounding urban nodes and sites will contribute to reducing traffic congestion, limit cars' usage and increase pedestrian and cycling movement within the transit village. By providing a high quality and easy access to the transit stations and its surroundings through walkways and crosswalks, interconnecting with various modes of public transportation and public open spaces will allow to maximising the use of areas to socialize and/or to increase opportunities for social activities. Figure (13) shows pedestrian bridges to enhance the connectivity from the station to the surrounding areas.

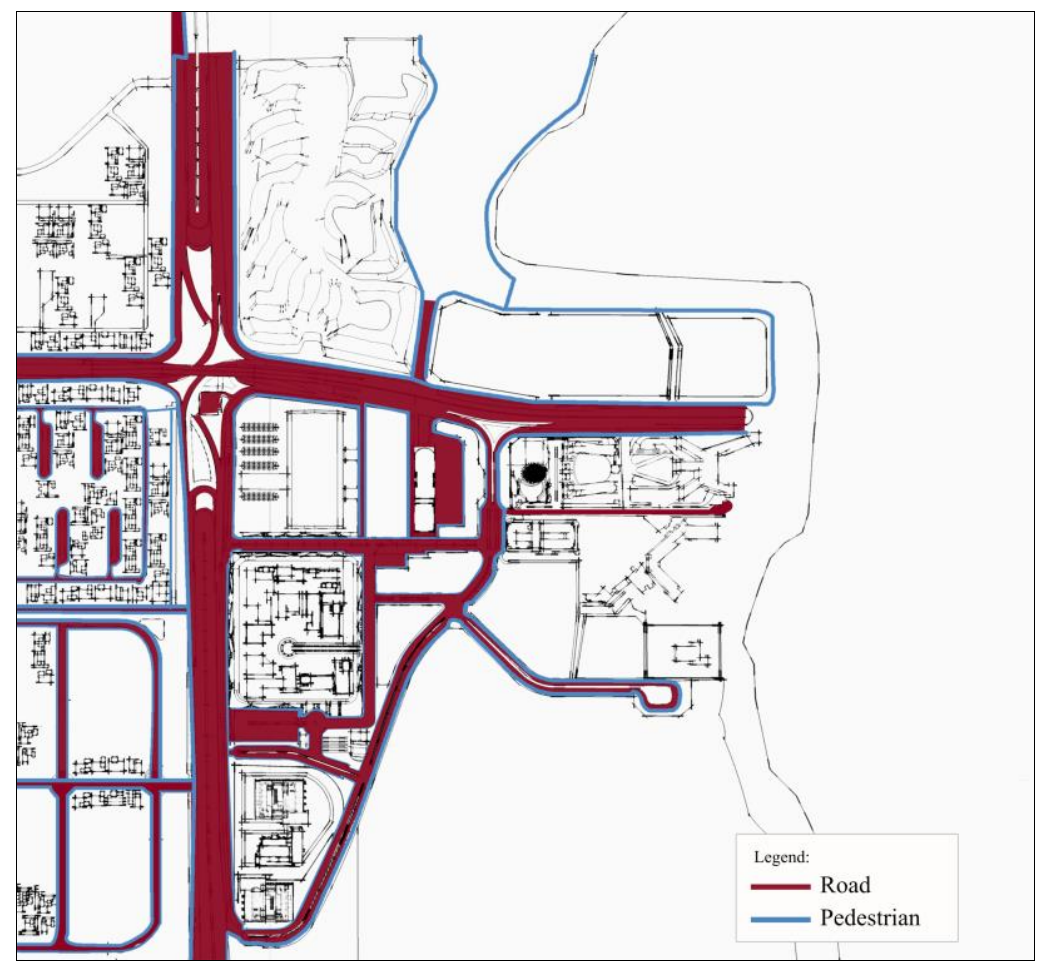

Figure 13. Roads and pedestrian Network (Source: Authors).

\section{Land Use}

The existing land-use is mostly set for residential and commercial use. As shown on figure 14, the neighbourhood includes mix exhibition centres and vacant areas. Residential areas, inclusive of villas and apartments, are primary located near the proposed metro station, retail and offices area. It is therefore cardinal to provide diverse housing options and suitable connection between existing residential uses and new higher density developments. The residential area is located within walking distance to public green areas and open spaces.

\section{Major Destination}

As anticipated, scholars envision mixed land use-urban developments, where users are allowed to meet their needs without extensive use of their private cars. One of the smart growth key-principles is to provide access to major facilities within walking distance. This principle promotes the creation of human-scale pedestrian neighbourhoods, within a community supported by social services and a built 
environment fostering urban connectivity. Figure 16 shows the location of the existing major destination in relation to the station, accessible through pedestrian and bicycle networks.

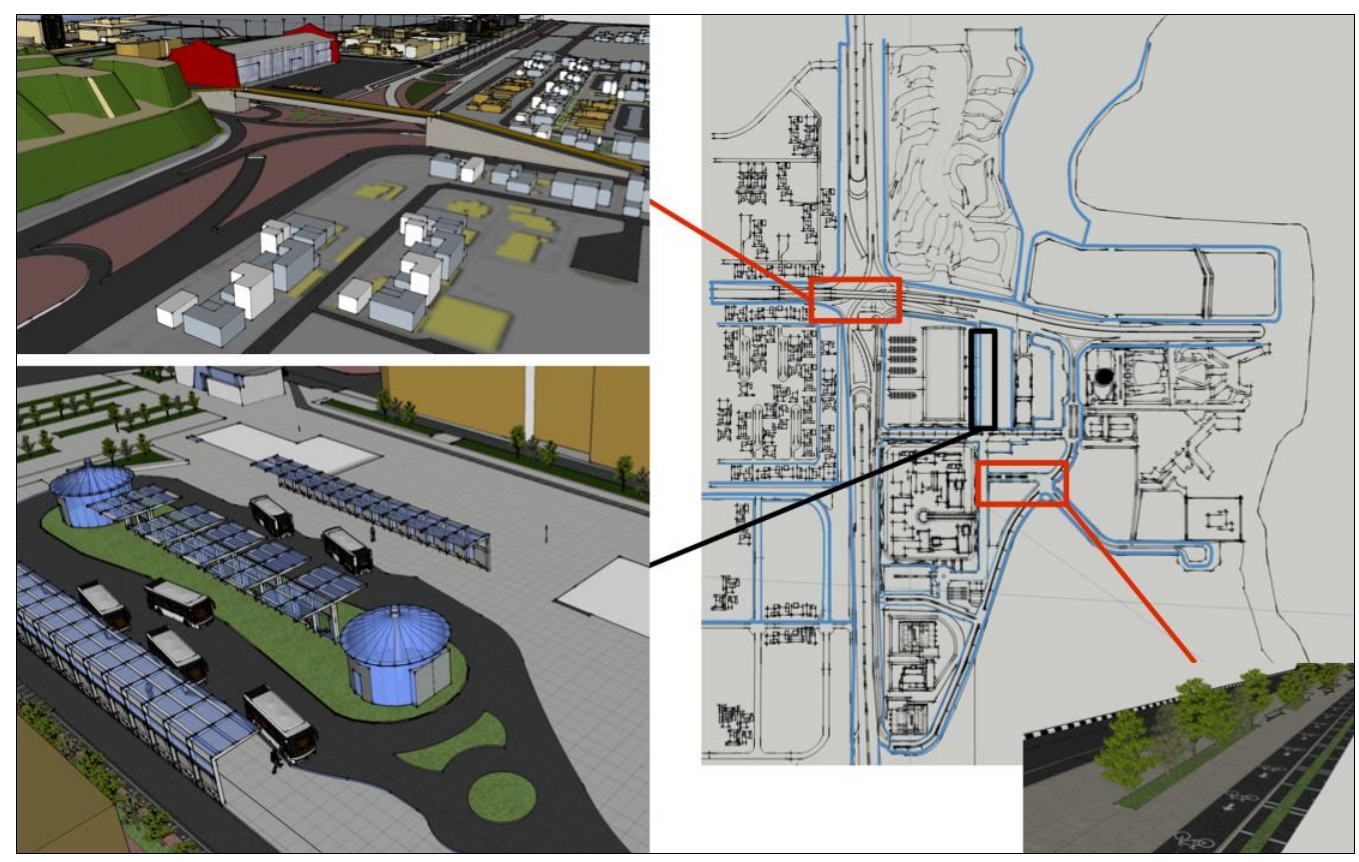

Figure 14. Transportation system (Source: Authors).

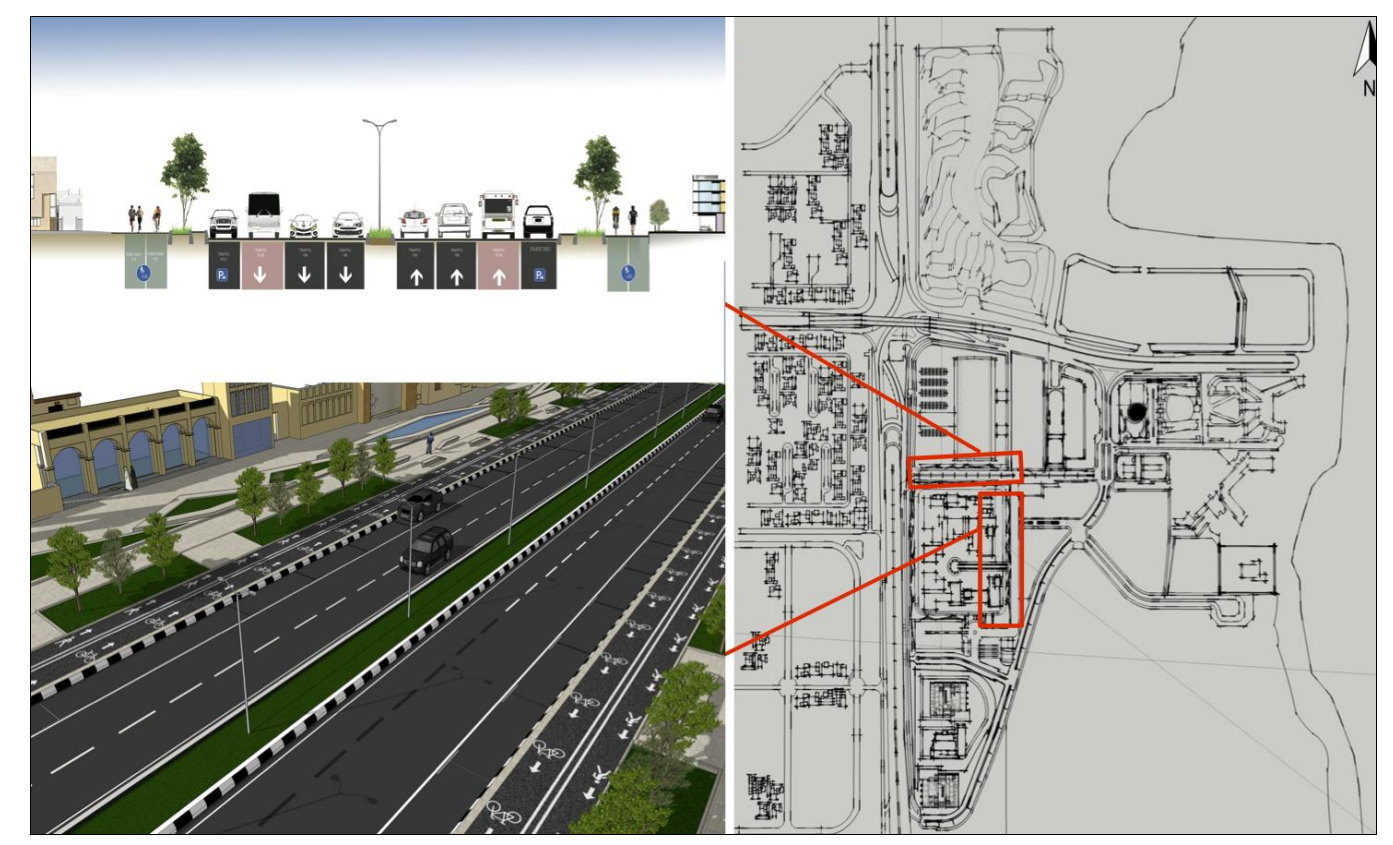

Figure 15. Pedestrian's realm (Source: Authors). 


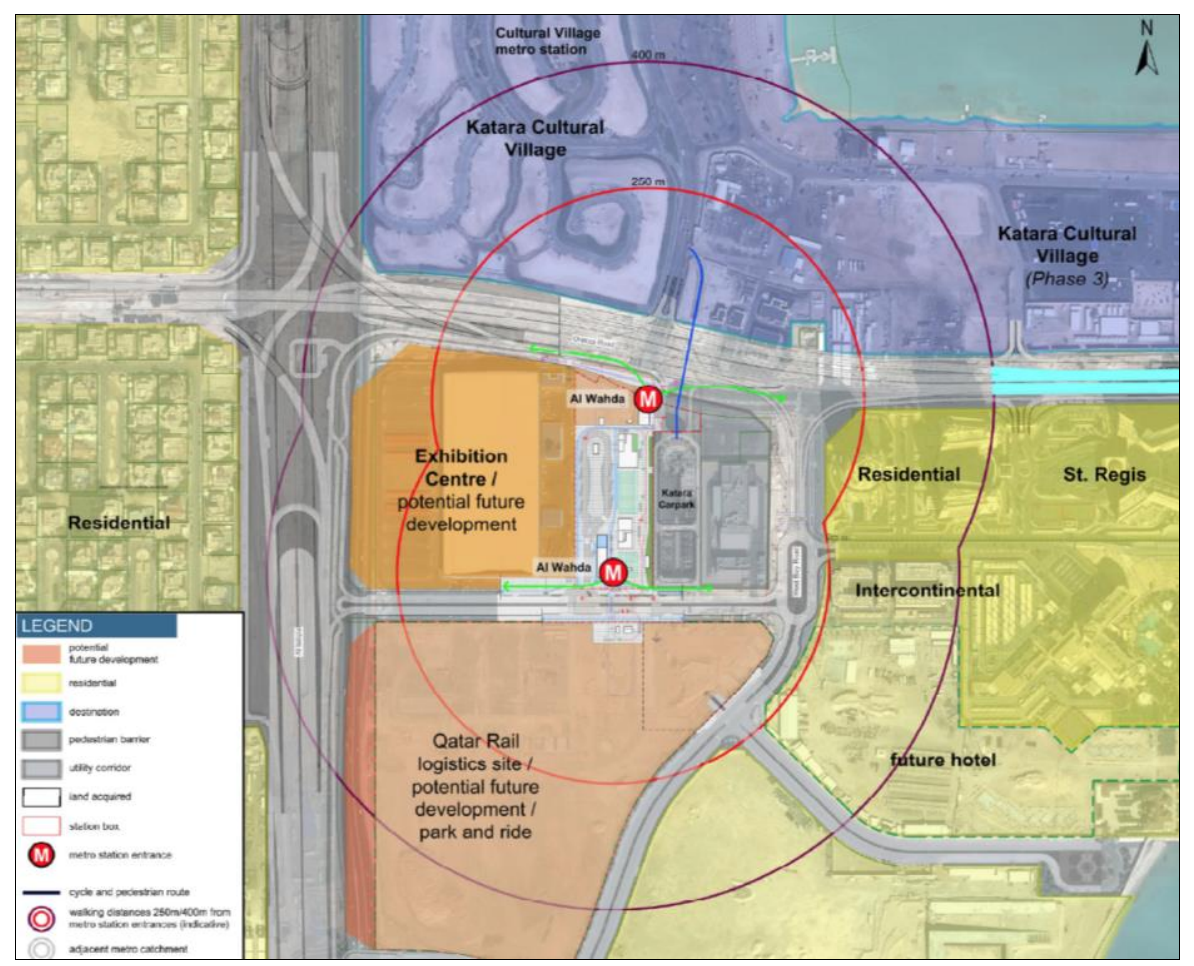

Figure 16. Existing land use (Source: Authors).

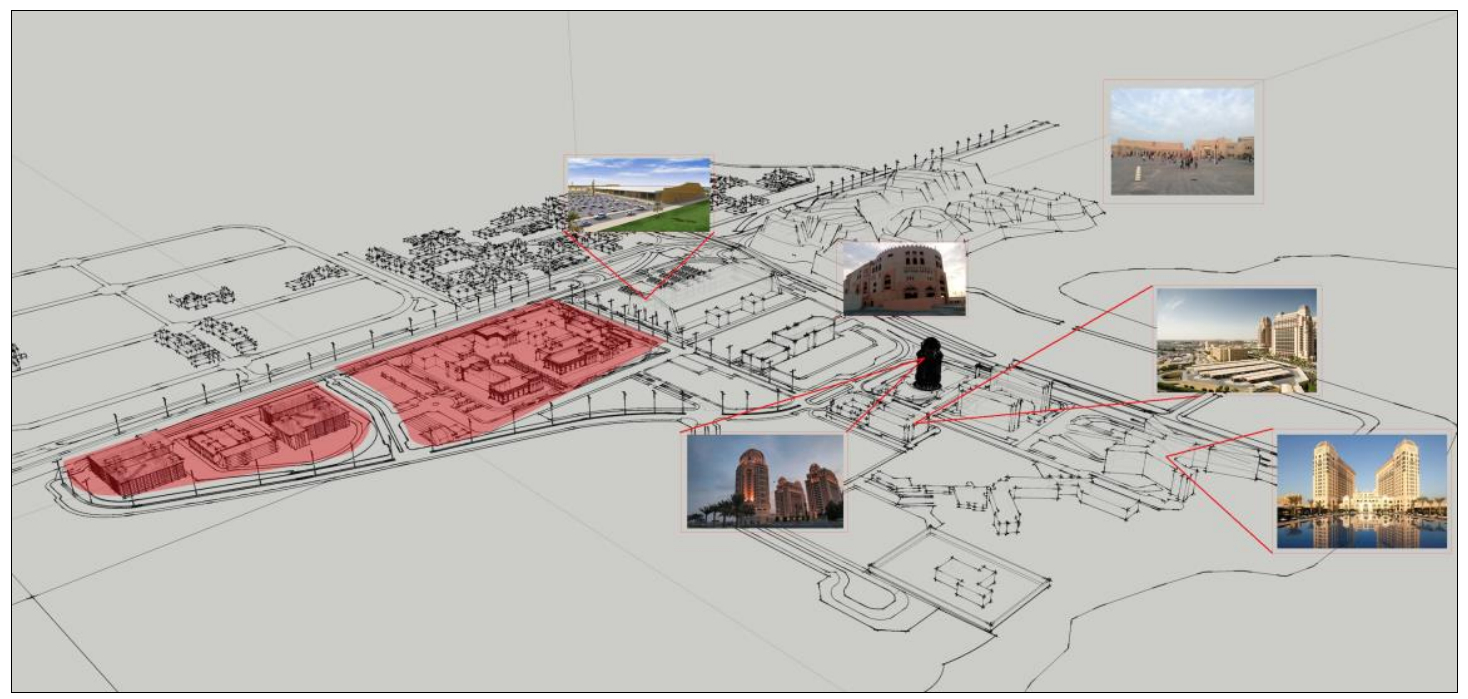

Figure 17. Major destinations (Source: Authors).

\section{Density (Neighborhoods)}

Mixed-use developments provide the arena to users belonging to different cultural groups to socially interact within open spaces in the proximity of public transportation and/or within walking distance. New urbanism and smart growth movement encourages providing diversity within new urban developments. The formation of compact multi-use urban areas, enclosing conveniently located and 
easily accessible schools, shops and services will also facilitate the overall urban sustainability of the district, reduce the use of cars and promote social activities.

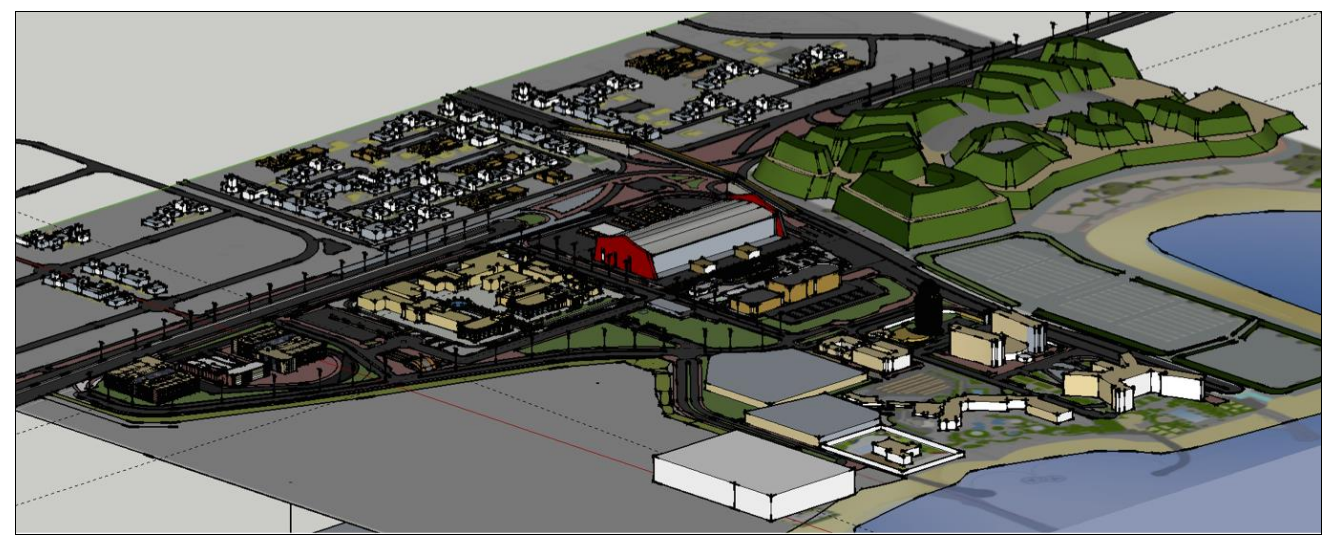

Figure 18: Density (Source: Authors).

\section{Natural Environment (Landscaped public realm)}

Green urbanism scholars envision the planning of sustainable developments by reducing the negative impact on the environment. In turn, they argue that this strategy will contribute to enhance users' quality of life within the urban development. By implementing green areas and trees the negative impact on the microclimate condition will be reduced. One of the major green urbanism principles stressed by scholar is based on the enhancement of the landscape, due to the major role of this factor in improving human comfort in hot arid region such as Qatar: green areas and trees provide a natural shading system, which contribute to reduce the temperature.
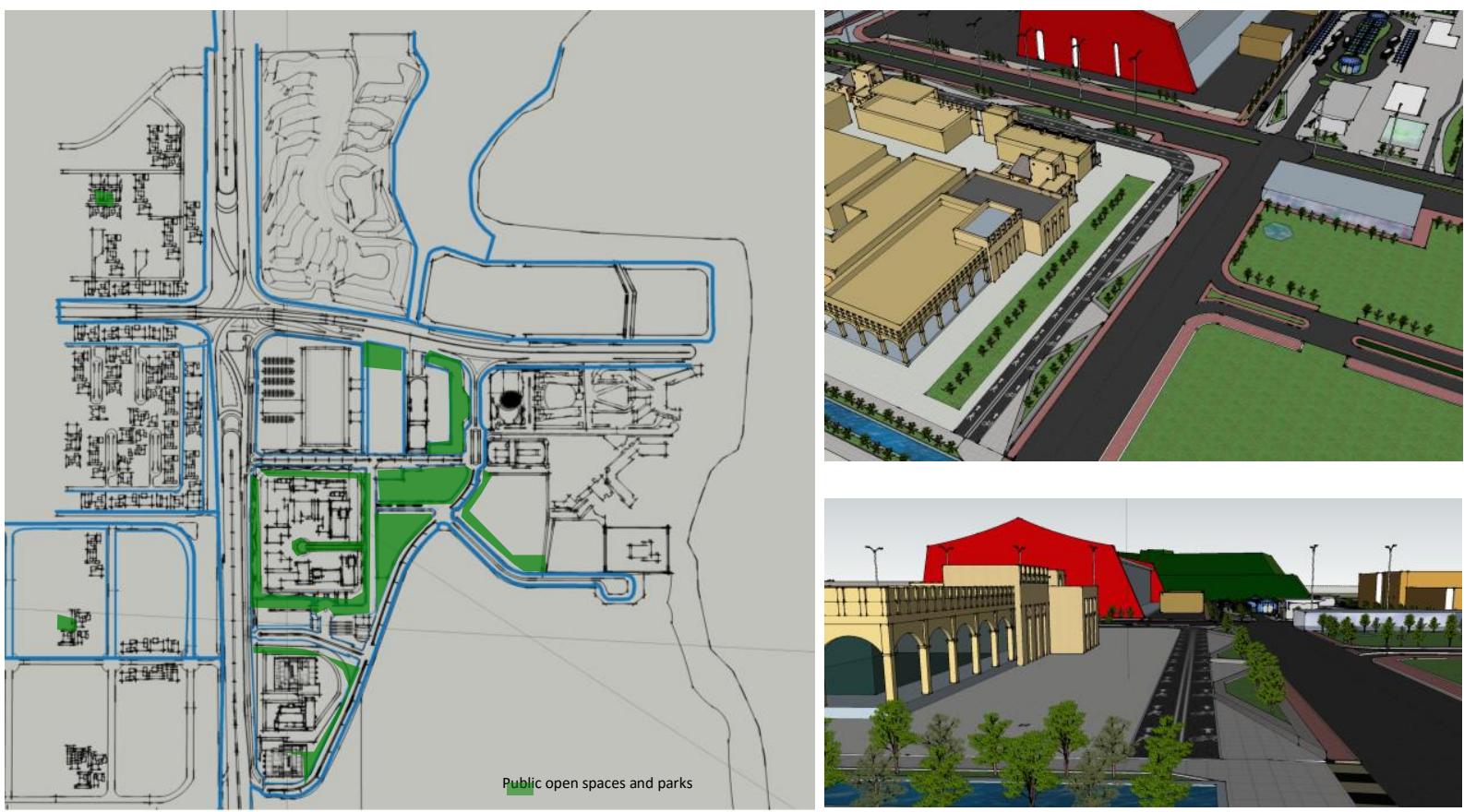

Figure 19. Garden and public open spaces (Source: Authors).

Archnet-IJAR, Volume 10 - Issue 3 - November 2016 - (170-192) - Original Research Articles 


\section{A Comprehensive Planning-Proposal for AL-Qassar's TOD}

The proposed land-use for the AI Qassar's TOD is shown on figure 20. The development of a compact mixed-use community, within walking distance to the station, allows enhancing liveability. The provision of diverse housing options and suitable connection between existing residential areas and high density development also contributes to enhance livability. Figure 22 illustrates the building height (with no high-rise buildings). According to the smart and sustainable growth strategies, the provision of a safe and comfortable network for pedestrians encourage people to not rely on the use of cars, and affect people behaviour in accepting other modes of transportation, such as the metro and/or bus transit systems. In turn, these strategies contribute to reducing congestions and improving the liveability and/or quality of life of the users.

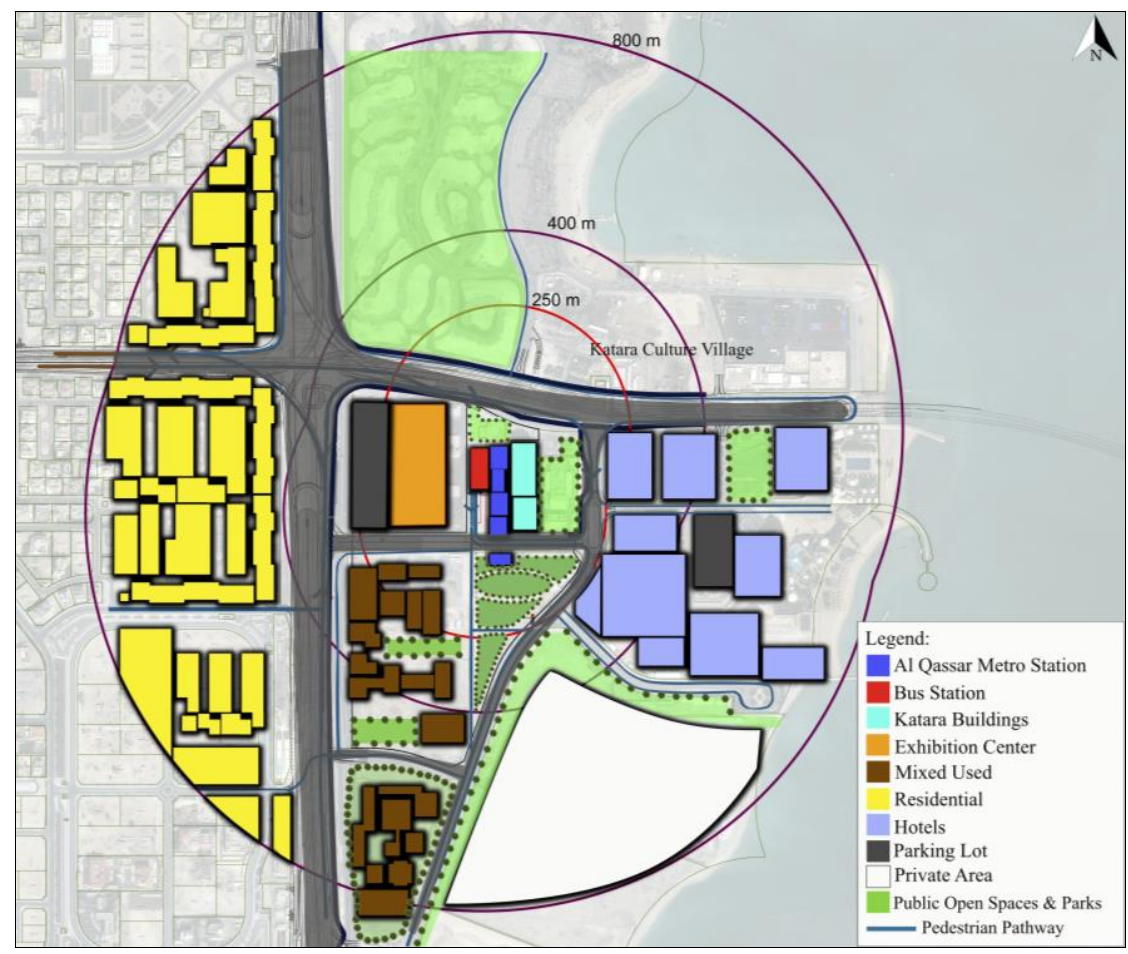

Figure 20. Al Qassar TOD's land-use (Source: Authors).

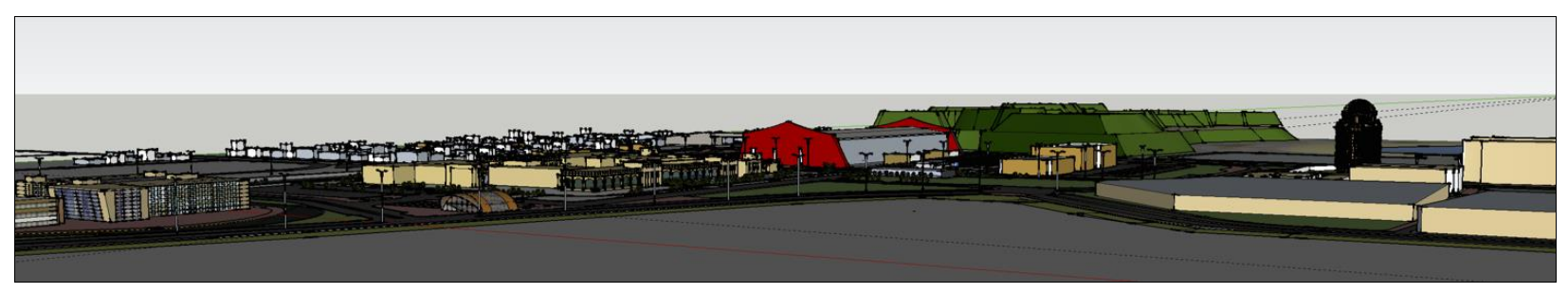

Figure 21. Building height (Source: Authors). 


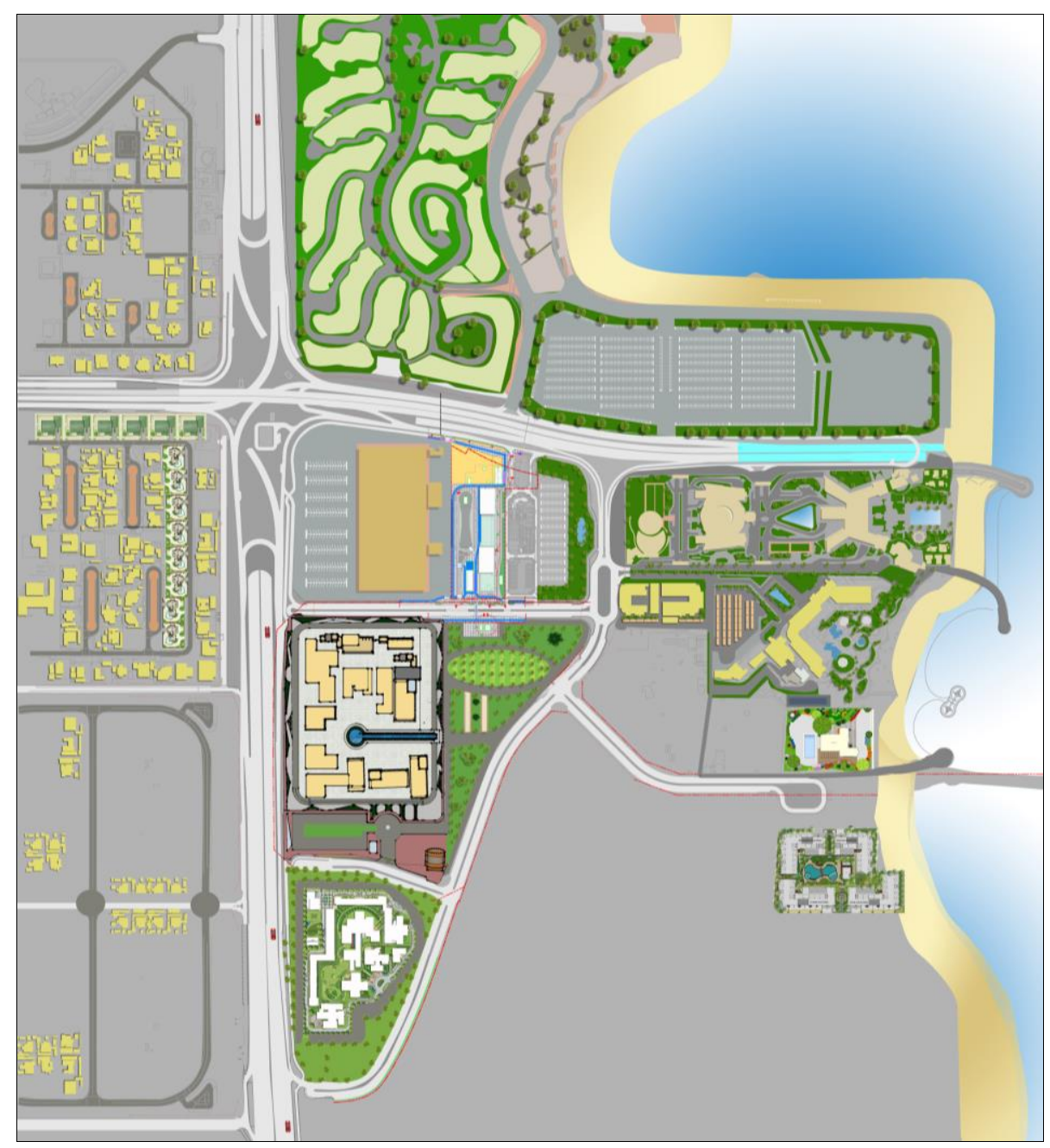

Figure 22. the transit village of AL-Qassar (Source: Authors).

\section{DISCUSSION AND CONCLUSIONS}

Scholars argue that the built environment, as well as its built forms, should provide the setting for human activity (Korllos, 1980, p. 247; Ross, 1991). They also stress that in the contemporary development of the built environment, practitioners, urban planners and policy makers should not ignore or fail to take into appropriate consideration the individuals' daily needs. World widely cities often experienced the planning and development of settlements built through an imposed formula dictated by standardization, speculation and/or for profit purposes where multi-disciplinary researchers and practitioners did not have a deciding role in the creation of the built form.

In addition, researchers highlight that over the last several decades, the urban fabric of cities has been less often designed in a way that resembles the traditional, mixed-use, pedestrian-oriented model and, as a consequence, the development of the built environment has been moving into a direction that have a negative effect on users' social interactions and/or capital. Despite the literature about the negative impact of car-dependent designed and sprawling suburbs on users' quality of life and/or way of life, it is argued that the trend is still to plan modern car-dependent transit villages and communities planned. This notorious tendency toward building car-oriented and less walkable

Archnet-IJAR, Volume 10 - Issue 3 - November 2016 - (170-192) - Original Research Articles 
communities is the result of speculative policies, of public zoning's codes, clearly promoting transport by private vehicle, and by a lack of planning policies leading to smart growth-urbanism. It is a trend deemphasizing public transport, and discouraging the building of mixed-use, pedestrian-oriented neighborhoods (Elsheshtawy, 2004).

Therefore, changing this trend will require formulation of planning policies towards the creation of new pedestrian oriented transit villages and the discouragement of sprawls of car-oriented communities. An integrated planning approach can lead to the concurrent construction of an efficient transit system (for example the rail way system) and of a livable built environment (for example a transit village): this approach can determine the extent to which users perceive these communities as vibrant and livable environments. In the urban design and planning of new districts, livability, as a factor humanizing the space and/or enhancing quality of life, is the major criteria to be addressed. An approach to implement or humanize the planning of transit villages should be based on a collaboration strategy among multidisciplinary planners and practitioners. This would see multi-disciplinary professionals and scholars being collaboratively involved in the final comprehensive urban design and planning of the built environment of cities. Urban planners, architects, transportation planners and all multi-disciplinary consultants should cooperate to deliver a comprehensive design, which ultimately enhances the livability of the neighbourhood. Policies are continuously drafted and approved by authorities to implement the development of the built environment and its livability. Strategies for intervention approved by local authorities should always aim at humanizing the built environment and/or enhancing users' quality of life.

It is hoped that the outcome revealed though this study could help in translating these research findings into practice, namely into comprehensively planning the urban fabric of new communities with the purpose to enhance users' quality of life and/or livability. In addition, since Qatar recognizes the crucial issue of smart growth-urbanism in QNV 2030, the outcome from this research study can contribute to define the comprehensive approach in planning transit villages in Qatar.

\section{FUTURE RESEARCH OPPORTUNITIES}

Integrating land use as well as making transport efficient is decisive in transforming Doha's urban structure and in creating transit villages and/or vital and livable communities. In relation to future research opportunities, an interesting issue raised during this research study is related to the way and the extent to which cultural identity and/or culture as a way of life can contribute to the implementation of the built environment of cities. Consequently further studies analysing the relationship between cultural identity and built form, namely at an urban and architectural design scale, could be engaged (1) to provide a deep understanding of how culture as a way of life can influence the urban planning of transit villages in Qatar and (2) to suggest a comprehensive framework for the future development of the city (Amit-Cohen, 2005; Furlan \& Faggion, 2015b). In turn, the dialectic relations between the city and its cultural urban identity could contribute to shape an integrated urban planning strategy for establishing Doha as the cultural, economic and service hub of Middle East, which is the ambitious and prestigious role envisioned by QNV 2030 for Qatar.

\section{ACKNOWLEDGEMENT}

The authors would like to acknowledge the support of Qatar University for creating an environment that encourages scientific research. This research study was developed as an assignment at the corecourse 'Urban Design in Practice' (MUPD-711, Fall-2015) for the Master in Urban Planning and Design Program (MUPD) at Qatar University. Also, this study is part of a research project scheme (QUSG-CENG-AUP-14\15.2) funded from Qatar University, College of Engineering, Department of Architecture and Urban Planning (DAUP). The authors would like to express their gratitude to the leading planners and architects from Qatar's Government Agencies and Ministries, namely to the Ministry of Municipality and Urban Planning (MMUP), Ashghal-Public Works Authority and Qatar Rail Archnet-IJAR, Volume 10 - Issue 3 - November 2016 - (170-192) - Original Research Articles 
for their collaboration, for participating in the meetings, handling relevant visual data and cardinal documents to the research aims and finally to discuss the conclusive results of this investigation. Finally, the authors thank the anonymous reviewers for their comments, which contributed to an improvement of this paper. The authors are solely responsible for the statements made herein.

\section{REFERENCES}

Alexander, C. (1987). New Theory of Urban Design. Oxford: Oxford University Press.

Amit-Cohen, I. (2005). Synergy between Urban Planning, Conservation of the Cultural Built Heritage and Functional Chnages in the Old Urban Center-The Case of Tel Aviv. from Elsevier

Besser, L., \& Dannenberg, A. (2005). Walking to Public Transit: Steps to Help Meet Physical Activity Recommendations. American Journal of Preventive Medicine, 29(4), 273-280.

Brown, L. J., Dixon, D., \& Gillham, O. (2014). Urban Design for an Urban Century-Shaping More Liveable, Equitable, and Resilient Cities. New Jersey, USA: John Wiley \& Sons.

Calthorpe, P. (1993). The Next American Metropolis: Ecology, Community, and the American Dream. New York: Princeton Architecture Press.

Calthorpe, P., \& Fulton, W. B. (2001). The Regional City-Planning for the End of Sprawl. Washington: Island Press.

Carmona, M., Tiesdell, S., Heath, T., \& Oc, T. (2010). Public Places Urban Spaces-The Dimension of Urban Design. New York, USA: Routledge.

Cervero, R. (2000). Walk-and-Ride: Factors Influencing Pedestrian Access to Transit. Journal of Public Transportation, 3(4), 1-23.

Cervero, R., \& Kockelman, K. (1997). Travel Demand and the 3Ds: Density, diversity adn Design. Transportation Research: Transport \& Environment, 3(2), 199-219.

Conan, M. (2000). Environmentalism in Landscape Architecture. Washington, DC: Dumbarton Oaks.

Corner, J. (Ed.). (2006). The landscape Urbanism Reader New York: Princeton Architectural Press.

Creswell, J. (1994). Research Design, Qualitative and Quantitative Approaches. Thousand Oaks, California: Sage Publications.

Creswell, J. (2003). Research Design: Qualitative, Quantitative and Mixed Methods Approaches (2 ed.). Thousand Oaks, California: Sage Publications.

Day, K. (2003). New urbanism and the challenges of designing for diversity. Journal of Planning Education and Research, 23(1), 83-95.

Denzin, N. K., \& Lincoln, Y. S. (2005). Handbook of Qualitative Research. London: Sage Publications.

Dierwechter, Y. (2013). Smart city-regionalism across Seattle: Progressing transit nodes in labor space? Geoforum, 49, 139-149.

Dunn, K. (2005). Interviewing. In I. Hay (Ed.), Qualitative Research Methods in Human Geography (pp. 79-105). Oxford: Oxford University Press.

Elsheshtawy, Y. (2004). Planning Middle Eastern Cities. An urban kaleidoscope in a globalizing world. London: Routledge.

Farr, D. (2008). Sustainable Urbanism - Urban Design with Nature. United States: Wiley.

Furlan, R. (2015). Liveability and Social Capital in West Bay, the New Business Precinct of Doha. Arts and Social Sciences Journal', 6(3), 1-11.

Furlan, R. (2016). Urban Design and Livability: The Regeneration of the Corniche in Doha. American Journal of Environmental Engineering', 6(3), 73-87. 
Furlan, R., Almohannad, M., Zaina, S., \& Zaina, S. (2015). Integrated Approach for the Improvement of Human Comfort in the Public Realm: The Case of the Corniche, the Linear Urban Link of Doha. American Journal of Sociological Research, 5(3), 89-100.

Furlan, R., Eissa, B., Awwad, R., \& Awwaad, R. (2015). Neighborhoods and Social Interactions: The Case of Al-Najada Area in Doha. American Journal of Sociological Research, 5(4), 119-133.

Furlan, R., \& Faggion, L. (2015a). The Development of Vital Precincts in Doha: Urban Regeneration and Socio-Cultural Factors. American Journal of Environmental Engineering, 5(4), 120-129.

Furlan, R., \& Faggion, L. (2015b). The Souq Waqif Heritage Site in Doha: Spatial Form and Livability. American Journal of Environmental Engineering, 5(5), 146-160.

Furlan, R., Muneerudeen, A., \& Khani, F. A. (2016). Urban Revitalization of Public Spaces in the Pearl in Qatar. American Journal of Sociological Research, 6(1), 1-9.

Furlan, R., N.Eiraibe, \& AL-Malki, A. (2015). Exploration of Sustainable Urban Qualities of Al Saad Area in Doha. American Journal of Sociological Research, 5(4), 101-118.

Furlan, R., Nafi, S., \& Alattar, D. (2015). Urban Built Form of the Souq Waqif in Doha and User's Social Engagement. American Journal of Sociological Research, 5(3), 73-88.

Givoni, B. (1989). Urban Design in Different Climates: World Metereological Organization Publication.

Hawkins, C. (2013). Competing interests and the political market for smart growth policy. Urban Studies, 51(12), 2503-2522.

Jamei, E., Rajagopalan, P., Seyedmahmoudian, M., \& Jamei, Y. (2015). Review on the impact of urban geometry and pedestrian level greening on outdoor thermal comfort. Renewable and Sustainable Energy Reviews, 54, 1002-1017.

Kaspirin, R. (2011). Urban Design-The Composition of Complexity. New York, USA: Routledge

Knowles, C., \& Sweetman, P. (2004). Picturing the Social Landscape: Visual Methods and the Sociological Imagination. London: Routledge.

Korllos, T. S. (1980). Sociology of Architecture: an emerging perspective. Ekistics, 47(285), 470475.

Lehmann, S. (2010). Green urbanism: Formulating a series of holistic principles. Sapiens, 3(2).

Marshall, C., \& Rossman, G. B. (2006). Designing Qualitative Research. London: Sage Publications.

Mason, J. (2001). Qualitative Researching. London: Sage Publications.

Miller, J. S., \& Hoel, L. A. (2002). The "smart growth" debate: Best practices for urban transportation planning. Socio-Economic Planning Sciences, 36(1), 1-24.

Remali, A. M., Salama, A. M., Wiedmann, F., \& Ibrahim, H. G. (2016). A chronological exploration of the evolution of housing typologies in Gulf cities. City Territory and Architecture, 3(14), $1-15$.

Ross, H. (1991). Household Compositions and Use of space. Social structure for Sustainability, Fundamental Questions Paper No. 11, Centre for Resources and Environmental Studies, Australian National University Canberra, 64-72.

Salama, A. M., Wiedmann, F., Thierstein, A., \& Al Ghatam, W. (2016). Knowledge economy as an initiator of sustainable urbanism in emerging metropolises: the case of Doha, Qatar. Archnet-IJAR: International Journal of Architectural Research, 10(1), 274-324.

Salama, A. M. \& Wiedman, F. (2013). Demystifying Doha: On architecture and urbanism in an emerging city. London: Routledge.

Salama, A. M., Khalfani, F., \& Al-Maimani, A. (2013). Experiential assessment of urban open spaces in Doha. Open House International, 38(4), 47-57. 
Salama, A. M., \& Wiedmann, F. (2013). The production of urban qualities in the emerging city of Doha: urban space diversity as a case for investigating the 'lived space'. Archnet-IJAR: International Journal of Architectural Research, 7(2), 160-172.

Saliba, R. (2015). Urban Design in the Arab World: Reconceptualizing Boundaries (Design and the Built Environment). US: Routledge.

Shaaban, K., \& Radwan, E. (2014). Rebuilding the Transportation System in the City of Doha. Journal of Traffic and Logistics Engineering 2(3), 241-247.

Steiner, F. (2011). Landscape ecological urbanism: Origins and trajectories. Landscape and Urban Planning, 100(4), 333-337.

Wey, W. M., \& Hsu, J. (2014). New urbanism and smart growth: Toward achieving a smart National Taipei University District. Habitat International, 42, 164-174.

Wiedmann, F., Mirincheva, V., \& Salama, A. M. Urban Reconfiguration and Revitalisation: Public Mega Projects in Doha's Historid Centre. Open house international, 38(4), 27-36.

Zeisel, J. (1984). Inquiry by Design: Tools for Environment-Behaviour Research. Cambridge: Cambridge University Press.

Zook, J. B., Lu, Y., Glanz, K., \& Zimring, C. (2011). Design and pedestrianism in a smart growth development. Environment and Behavior, 44(2), 216-234.

\section{AUTHORS}

\section{Dr Raffaello Furlan}

Assistant Professor of Architecture and Urban Design

College of Engineering, Department of Architecture and Urban Planning,

Qatar University, Doha, State of Qatar

Email: raffur@gmail.com

\section{Mooza AlMohannadi}

Urban Planner, BA (Hons) Geography and Urban Planning (Qatar University, Qatar)

Candidate - Master in Urban Planning and Design

College of Engineering Department of Architecture and Urban Planning,

Qatar University, Doha, State of Qatar

Email:moza89.saqr@gmail.com 